\title{
Discussion on the relationship between shipowners and shippers under the new shipping situation
}

\author{
Shu-ai Wu \\ Qingdao Ocean Shipping Mariners College, Qingdao 266071, China \\ wusa001@126.com
}

Key words: shipowner, shipper, relationship, mode

Abastract. The shipping industry has been in a slump in recent years. At the same time, internet thinking has brought great influence to the shipping industry. The shipowners have been exploring new business models, and the relationship between the shipowners and the shippers is in a delicate state. Under the new shipping situation, how can the the shipowner and the shipper achieve mutual benefit? This paper deeply analyzes the relationship between the shipowners and the shippers, pointing out that the cooperation between both parties is coming into a new era of modern logistics, and that the shipowners should strengthen the cooperation with the owner to enhance the capacity of service for the shippers, and that new ideas, new business model will give the shipowners and the shippers better prospects for development.

\section{Introduction}

Shipping industry cycle fluctuation is strong, and the market prospect is hard to predict, which are very bad for either shipowners or the shippers. These uncertainties are both a challenge and an opportunity for shipowners and shippers.

\section{From game to cooperation between the shipowners and the shippers}

The shipowners and the shippers are both parties of the contract of carriage of goods by sea, which is the upstream and downstream relationship of the maritime transport supply chain. The game between them has a long history. Since the middle of the 19th century, shipping overlord British insists on the principle of "freedom of contract", by allowing the carrier by the terms of the contract to change the entrust system and common law implied obligations, and prescribe some clause in the bill of lading to alleviate his responsibility or exclude the obligations stipulated in the common law as the carrier to determine the carrier of the dominant position. This state has been in effect until 1893 when the American "Hart ACT" was enacted, which greatly safeguarded the interests of American shippers. The American "Hart ACT" promulgate thus opened the game process between both the shipowners and the shippers.

In addition, the evolution process from the Hague rules, "Visby's rule rules to the Hamburg rules reflects the interests balance on both sides, and also reflects the process of the shipowner and the shipper's game from the perspective of maritime cargo transport legislation.

The shipping industry is very unstable, and the ability of controlling the risk of the whole industry is very weak. The international financial crisis has led to a sharp decline in international trade, and the shipping industry is facing a deep trade recession. What's the trend of the relationship between the shipowners and the shippers? Whether they will continue to play the game or stay 
together to keep warm each other? Different relationships between them will cause different consequences.

In the first case, if they continue to play games along the shipping market, there will be shipowners' excess capacity, rate decline, ship empty, and shipowners will operate at a loss, and even some small shipowners could be forced to exit the shipping industry; At the same time, in this case the shippers must also are affected. The collapse in international trade will led to a contraction in the volume of goods. At the same time, due to the decline of some shipowners in the market, the shipping industry competition will weaken largely, and both shipowners and shippers will suffer heavy losses.

Another case is that if the shipowners and shippers can cooperate through various forms, such as through a long-term freight rate agreement between shipowners and shippers to cover loss cost of the shipowners so that the shipowner can continue to maintain the operation under the financial crisis, on the other hand the shipowners improve service quality, and improve the ability of serving the shippers so that they can achieve win-win.

\section{The mode of cooperation between the shipowners and the shippers}

simple chartering and booking relationship

In this mode, the relationship between the shipowners and the shippers is very loose, and the cooperation between them is of great randomness. The shippers choose the shipowners according to transport demand and the freight rates, and there is no long-term close relationship of cooperation between the shipowners and the shippers.

Since the shipping industry is very unstable, and it is greatly influenced by the market, price volatility is stronger, this cooperation mode between the shipowners and the shippers based on the loose relationship usually leads directly that the shipowners haven't enough space to give the shippers at the peak, and at the same time the shippers have a hurry shipment but they have to face the shortage of the shipping space, which usually makes the trade delay. Furthermore, in this mode, shippers cannot obtain lower freight rates from shipowners, which directly determine the freight cost of shippers. Therefore, it is unwise for many shippers to choose this way, especially for the large shippers who have strict stipulations on letters of credit with foreign trade customers.

Strategic partnership

In this mode, the shipowners and the shippers usually sign a long-term cooperation agreement, under which the shipowners promise to give the shippers cargo space guarantee and the lower freight rates, and in the meanwhile the shippers promise to give the shipowners the relatively stable goods for a certain period of time to ensure the ship's shipping space. The two parties can realize information sharing, and jointly resist market risks.

This cooperation mode between the shipowners and the shippers is an ideal model, under which the shipowners can guarantee that the ship is fully loaded, and at the same time the shippers can get the ship capacity and a lower freight rate, therefore, it is a win-win condition for both parties. Therefore, from the point of the perspective of social division of labor and the supply chain under the modern large logistics, this mode of strategic cooperation between the shipowners and shippers is very ideal with the two sides' cost minimum against the biggest gain.

Capital bond

Under the market increasingly competitive environment, the shipowners and the shippers use their advantages to establish joint venture shipping companies, by which both parties makes them into a deeper cooperation investment partnership from the pure carriage relationship. Under this circumstance, the shippers are usually large energy giant in steel, oil, coal and other owners. In this 
mode, the shipowners have ship management experience and the shippers have a supply of goods, and they can combine the cargo supply and the ship management experience to achieve the maximum profit of the enterprise level and the maximization of social effect and at the same time to evade market risk.

In this mode, the cooperation between both parties must have a real win-win basis. This model, which is complementary and mutually beneficial, will be more complicated for both parties.

For the shippers, they only need to provide money and cargo supplies, and fleet management is mainly borne by the shipowners, so all kinds of resources and cost of the shippers will be reduced correspondingly, and then market risk is reduced. At the same time, because the cooperation between both parties is on the basis of the shippers' cargo transportation, the joint venture shipping companies can realize the seamless docking of the cargo and the ship in capacity control, route configuration, cargo arrangement and so on to. But, because of the logistics transportation management control is not entirely in the hands of the shippers themselves, which should be shared with the shipowners and also interests should be shared, all these largely restrict the shippers.

Shippers self-built a fleet operating the vessels

In order to control the initiative of the entire production and logistics supply chain, and also to avoid possible suffers from some shipowners against regulatory restrictions, some large gaints especially in the iron and steel, petroleum, coal mining build a fleet entering into the shipping market.

On the surface, the shippers' self-built fleet seems to make them get rid of the disadvantages such as the shipowners' irrational price increases and various additional expense, but how about the future of the shippers' self-built fleet? From the perspective of market specialization and historical experience, the shippers' fleet is less professional than professional shipping companies, and its shipping safety cannot be guaranteed, furthermore because shipping industry is a strong cyclical industry together with the profitable peak and losing money trough, huge profits with the profitable peak and a short-term prosperity phenomenon are just illusion.

The advantage of this model is that the shippers have more controlling for the traffic volume, routes and freight rate, and the disadvantage is that the shippers lack the professional knowledge of the management of the fleet, once the shipping market downturn, vessels will become idle resources, at the same time the fleet will be hold up by the market, and the risk of shipping market will be fully borne by shippers themselves. The shippers of many countries around the world do not build their own fleets. Instead, they expand their business according to economic law and social development, and choose to cooperate with the shipping company.

By comparing the above four ways, for the shippers, the ideal is the second mode under which the shipowners and the shippers arrive the long-term strategic cooperation, which reflects not only the traditional sense of the simple charter booking between the shipowners and shippers, but reflects an in-depth logistics service cooperation of the modern transportation under the supply chain between both parties, conforms to the modern transportation mode between the shipowners and the shippers ' social trend of specialization of division of Labour cooperation, meets the needs of the development of the modern supply chain.

\section{The cooperation significance between the shipowners and the shippers}

The cooperation between the shipowners and the shippers is mutually beneficial and win-win. For professional ship company, since they have operated for many years, and they have accumulated much more rich experience with a large number of professional personnel, they can 
provide better service and lower prices to the shippers, in the meanwhile, the shippers can provide a stable cargo resource for shipowners, and then provide guarantee for shipping company's capacity.

Be conducive to the mutual development between the shipowners and the shippers to realize the complementary advantages

With the deepening of economic globalization, shippers need to expand their business around the world, and there is a growing demand for specialized industries. In the meanwhile the shipowners have intensive schedule, reasonable distribution of global navigation, which can provide the shipper with internationally competitive rate and complete supply chain services, and make the shippers get safe and intimate service.

At the same time, the shipowners can rely on the cargo flow of the shipper to open new routes on the basis of the original routes. In the early time of Hisense cooperation with COSCO liner shipping, for example, COSCO based on some Hisense inland point of transportation services in Hungary and France, relying on the amount of Qingdao Hisense containers successfully opened three new logistics routes, and then expanded the shipowners' the sealine service.

Be conducive to the establishment of a long-term and stable price model between the shipowners and the shippers

The shipowners can provide the long-term and stabile freight rates for the shippers, and both parties will be confirmed at the beginning of each calendar year into the shipping price of each shipment port and in a controlled market price fluctuation range to maintain price stability, which can make the shippers effectively circumvent the affect which is caused by the shipping market price fluctuations on the transportation cost accounting, reduce the transportation cost, improve the competitiveness of the shippers' products, and then it is advantageous to the shipowners and the shippers so as to establish a long-term and stable relationship against the market risks.

Be conducive to the realization of the sharing of information resources between the shipowners and the shippers to improve the delivery efficiency of goods

In the above example, after the cooperation between COSCO and Hisense, COSCO personnel were sent in Hisense to increase the opportunity to understand Hisense business, which makes both sides have an in-depth understanding of each other's operating procedures and business characteristics. Through the common development of information platform, they can mutually understand the information of the production and the inventory and shipping space, and so on. Both parties greatly improve the accuracy and security of the transport of goods, reducing the damage of shortage through the information sharing, mutual consultation, and improve the goods process through communication, so as to make full use of shipping capacity, reducing the transportation cost.

\section{Conclusion}

Usually, the relationship between the shipowners and the shippers is a unity of opposites. New ways of thinking, new strategies and new business models will give the shipowners and the shippers a better outlook. Under the new strategic model, the shipowners and the shippers should seek a new type of partnership and propose sustainable solutions to ensure that both parties continue to have a chance to survive.

The cooperation between COSCO and Hisense is a good example of the companies to keep warm each other under financial crisis situation, and it's also the inevitable road of the cooperation of the shipowners and the shippers. Cyclical fluctuations in shipping market characteristics determine that the shipowners must establish the long-term stability of the new strategic partnership with the shippers. At present, the cooperation between the shipowners and the shippers is entering 
into the era of modern logistics, the shipowners should enhance the stability and continuity of supply chain and strengthen the construction of logistics information network so as to improve the ability serving the shippers.

\section{References}

[1] Shipowners and shippers should enhance the level of cooperation.

http://info.jctrans.com/news/cgs/20111181101542.shtml

[2] China-EU strategic cooperation is mutually beneficial and has far-reaching significance.

http://news.10jqka.com.cn/20120220/c525945119.shtml

[3] Shippers should make full use of the professional advantages of shipping enterprises.

http://www.dayoo.com/roll/201108/10/10000307_104687598.htm

[4] Shippers and shipping companies should build closer partnerships.

http://www.zghylm.com/html/04/t-52204.html

[5] Nian Zhang, Hui Xie, "The cooperative relationship between ship company and shipper in port supply chain", Market modernization, [J].2008 ( 5 ) : 142-143. 